\title{
Gambaran Kehidupan Wanita yang di Poligami
}

\author{
Mohammad Khasan \\ Fakultas Psikologi, Universitas Muria Kudus \\ khasanm86@gmail.com \\ Sujoko \\ Fakultas Psikologi, Universitas Setia Budi Surakarta \\ agussujoko85@gmail.com
}

\begin{abstract}
The phenomenon of polygamy in Indonesia is still a polemic in society. One of them was during the speech by the chairman of Indonesian Solidarity Party (PSI) Grace Natalie at East Java Expo on Tuesday (11/12/2018) which stated that "PSI will never support polygamy". The objective of this study is to find out how the life phenomenon on polygamous women in Surakarta. The method used is a qualitative approach using interviews as a method of collecting data. The results of this study indicate that basically women who will be polygamous will emerge various kinds of feelings such as: distrust, sadness, anger, disappointment, and hurt. Nevertheles, a woman must obey or accept whatever her husband wants, this is due to the child, the future wife is pregnant out of wedlock, threatened to be divorced, and orders from God in Islamic law.
\end{abstract}

Key word: the phenomenon of life; women in polygamy.

\begin{abstract}
Abstrak
Fenomena poligami di Indonesia masih menjadi polemik di masyarakat. Salahsatunya pada saat pidato ketua umum Partai Solidaritas Indonesia (PSI) Grace Natalie di Jatim Expo Selasa malam (11/12/2018) yang menyatakan bahwa "PSI tidak akan pernah mendukung poligami", Tujuan dari penelitian ini adalah untuk mengetahui bagaimana gambaran kehidupan pada wanita yang dipoligami di Surakarta. Metode Penelitian ini menggunakan pendekatan kualitatif dengan menggunakan wawancara sebagai metode pengumpulan datanya. Hasil dari penelitian ini menunjukkan bahwa pada dasarnya wanita yang akan dipoligami akan muncul berbagai macam perasaan seperti: tidak percaya, sedih, marah, kecewa, dan sakit hati. Namun dalam hal ini seolah-olah wanita harus siap menerima apapun yang diinginkan oleh suaminya hal ini disebabkan karena faktor anak, calon istri sudah hamil diluar nikah, mendapat ancaman untuk dicerai, dan syariat Islam dan ada perintahnya dari Allah.
\end{abstract}

Kata kunci: gambaran kehidupan, wanita di poligami. 


\section{Pendahuluan}

Fenomena poligami di Indonesia masih menjadi polemik di masyarakat. Salah-satunya pada saat pidato ketua umum Partai Solidaritas Indonesia (PSI) Grace Natalie di Jatim Expo Selasa (11/12/2018) malam yang menyatakan bahwa "PSI tidak akan pernah mendukung poligami". Selain penyataan tadi, Grace mempertegas kembali yaitu "Tak ada kader PSI, pengurus, dan anggota legislatif dari partai ini yang boleh mempraktikkan poligami." (https://tirto.id/mengapapoligami-jadi-masalah-dcbp)

Selain fenomena diatas, berdasarkan petunjuk kitab suci al-Qur'an, tujuan pernikahan adalah membentuk keluarga yang sakinah, mawaddah wa rahmah. untuk mencapai tujuan tersebut, terdapat beberapa prinsip yang harus dipedomani, baik oleh suami, maupun istri, yaitu; 1) prinsip kebebasan dalam memilih jodoh, 2) prinsip cinta kasih, 3) prinsip saling melengkapi dan mendukung, dan 4) prinsip mu'asyarah bi al-ma'ruf (Mulia, 2004).

Selain menawarkan empat prinsip yang dijelaskan di atas, Perlu ditegaskan di sini bahwa tujuan disyariatkannya hukum Islam adalah untuk kemaslahatan manusia. Dengan prinsip seperti ini, jelaslah bahwa disyariatkannya poligami juga untuk kemaslahatan manusia. Poligami bertujuan untuk mewujudkan keluarga yang baik, bukan semata-mata untuk menyenangkan suami. Dari prinsip ini juga dapat dipahami bahwa jika poligami itu tidak dapat mewujudkan kemaslahatan, maka poligami tidak boleh dilakukan. Karena itulah, Islam memberikan aturanaturan yang dapat dijadikan dasar untuk pelaksanaan poligami sehingga dapat terwujud kemaslahatan tersebut (Marzuki, 2005)

Di antara konsep pernikahan yang ditawarkan oleh Islam adalah pernikahan monogami dan poligami bersyarat. Konsep pertama merupakan pengejawentahan dari janji setia dan cinta kasih yang diikrarkan oleh suami istri. Sementara itu, konsep kedua mencerminkan realitas sosiologis kaum laki-laki dan budaya patriarkhis-Arab yang diakomodir serta dimodifikasi oleh Islam (Nurmila, 2015). Konsep ini yang kemudian diadopsi oleh banyak negara Islam, termasuk Negara Indonesia. 
Dalam UU No.1 tahun 1974, disebutkan bahwa azas pernikahan di Indonesia adalah monogami. Poligami hanya dibolehkan dengan syarat yang ketat dan dalam keadaan tertentu. Dalam Kompilasi Hukum Islam (KHI), asas monogami dan kebolehan poligami juga dibolehkan, namun dalam kondisi khusus, serta adanya pemenuhan beberapa syarat yang telah diatur diatur. Adapun dalam Peraturan Pemerintah No.10 tahun 1983 Peraturan Pemerintah No. 45 tahun 1990 dijelaskan tentang kebolehan poligami dengan syarat yang cukup ketat khususnya bagi anggota Pegawai Negeri Sipil (PNS) (dalam Ma'ruf: 2013)

Menurut Machali (2005), Meskipun telah memiliki landasan hukum dan dasar-dasar teologis yang kuat, tampaknya praktik poligami selalu mengundang kontroversi bagi beberapa kalangan. Tema poligami, sepertinya juga, selalu menarik untuk didiskusikan. Wacana mengenai poligami tidak hanya menarik bagi kaum laki-laki, yang menjadikannya sebagai obsesi hidup, namun juga bagi perempuan yang menganggap poligami sebagai sesuatu yang membahayakan kedudukan dalam rumah tangga. (Husein, 2007). Berdasarkan fenomena di atas, penulis tertarik untuk memberi kontribusi keilmuwan psikologi sosial dengan mewacanakan realitas sosial di masyarakat tentang poligami.

\section{Metode}

Fokus penelitian ini adalah mendeskripsikan gambaran kehidupanPada Wanita Yang di Poligami. Informan dalam penelitian ini adalah wanita yang dipoligami di Kota Surakarta. Penelitian kualitatif tidak dikenal istilah populasi dan sampel. Istilah sampel memiliki arti yang berbeda dengan sampel dalam penelitian kuantitatif inipun (Sugiyono,2009). Selain itu, penentuan jumlah informan dalam penelitian kualitatif ini tidak ditentukan pada awal penelitian, tetapi pada waktu proses penelitian berjalan. Hal ini dilakukan karena penentuan jumlah informan bisa sedikit atau banyak tergantung pada pemilihan informannya dan keragaman fenomena yang di teliti (Sugiyono, 2009). Sehingga apabila dalam rangkaian proses penelitian yang dilaksanakan, keterangan yang diberikan oleh informan sudah cukup dan terwakili seluruh atau sebagian besar aspek yang ingin digali oleh peneliti maka jumlah informan akan segera dibatasi. 
Penentuan informan dalam penelitian ini diambil dengan cara naturalistic sampling. Penentuan sampel dalam penelitian kualitatif (naturalistik) sangat berbeda dengan penentuan sampel dalam penelitian konvensional (kuantitatif). Penentuan sampel dalam penelitian kualitatif tidak didasarkan perhitungan statistik. Sampel yang dipilih berfungsi untuk mendapatkan informasi yang maksimum, bukan untuk digeneralisasikan.

Metode pengumpulan data yang digunakan untuk mengungkapkan permasalahan dalam penelitian ini adalah wawancara. Teknik wawancara dalam penelitian ini adalah wawancara langsung yaitu penulis berhadapan langsung dengan informan serta mengajukan beberapa pertanyaan. Teknik ini dimaksudkan agar penulis dapat memperoleh data-data secara langsung dari informan. Agar data-data yang diperoleh sesuai dengan hasil wawancara, maka dalam kegiatan wawancara ini penulis memakai alat bantu berupa hand recorder danguide wawancara. Adapun guide wawancara dalam penelitian ini adalah sebagai berikut:

Data penelitian kualitatif tidak berbentuk angka tetapi lebih banyak berupa narasi, deskripsi, cerita, dokumen tertulis dan tidak tertulis (gambar, foto) ataupun bentuk-bentuk non angka yang lain.

Penelitian ini bersifat kualitatif dengan pendekatan eksploratif maka analisis data yang digunakan adalah analisis data induktif deskriptif yaitu melakukan abstraksi setelah rekaman fenomena-fenomena khusus dikelompokkan menjadi satu. Analisis data dalam penelitian ini akan melalui beberapa tahap; 1) Organisasi data: Proses yang dilakukan dalam pengolahan data hasil penelitian yaitu dengan mengorganisasikan data. Hal-hal yang disimpan dan diorganisasikan adalah : (a) data mentah (catatan lapangan dan kaset), (b) data yang sudah ditulis dalam verbatim, (c) data yang sudah di tandai dengan kode-kode, (d) teks laporan (yang masih terus akan ditambah jika perlu, dan diperbaiki sesuai dengan perkembangan dan temuan lapangan).2) Koding: Setelah pengorganisasian data, selanjutnya dilakukan pengkodingan. Yaitu proses pengkodean atau pembubuhan kode-kode pada materi yang diperoleh dengan maksud agar dapat mengorganisasikan dan mensistemasi data secara lengkap dan mendetail sehingga data data dapat memunculkan gambaran tentang topik yang dipelajari. Koding 
dapat dilakukan melalui: (a) Penulis menyusun transkrip verbatim (kata demi kata) atau catatan lapangan sedimikian rupa sehingga ada kolom kosong yang cukup besar sebelah kanan dan kiri transkrip. Hal ini akan memudahkan untuk membubuhkan kode-kode atau catatan-catatan tertentu pada transkrip tersebut. (b) Penulis memberikan nama untuk masing-masing berkas dengan kode tertentu. 3) Menentukan tema: Cara menentukan tema, berdasarkan isi cerita informan (conten analysis). Setelah memberikan nama dan kode pada berkas, maka penulis membaca isi cerita dan memahami transkrip yang sudah dikoding, untuk mencari tema-tema penting. Dari isi cerita informan akan tampak tema yang dapat dikategorisasikan / dikelompokan berdasar tema yang sama.

Setelah itu penulis membaca transkrip verbatim berulang-ulang untuk mengidentifikasi tema-tema yang muncul. Pada tahap ini penulis melakukan interpretasi terhadap pernyataan informan penelitian, tetapi tetap sesuai dengan konteks penelitian yang dilakukan.Setelah itu penulis dapat menyusun pada lembar terpisah, "master" yang berisikan daftar tema-tema dan kategori-kategori, yang telah disusun sehingga memperlihatkan pola hubungan antar kategori cross cases (bukan kasus tunggal lagi).

\section{Hasil Penelitian}

\section{Informan 1}

\section{Perasaan dan Sikap Informan ketika Akan di Poligami}

Sebelum informan menikah, informan tidak pernah membayangkan kalau suatu saat akan di poligami oleh suaminya. Sehingga ketika suami mengatakan ingin menikah lagi, informan sempat tidak percaya dan sedih. Terlebih lagi saat itu, informan sedang mengasuh anaknya yang masih kecil. Rasa sedih informan semakin bertambah karena ternyata calon istri suaminya tersebut sudah hamil diluar pernikahan.

Oalah, pie yo mbak, yen mikir ning posisi ngene ki yo ora pernah mbak, blas ora pernah... ning kan gandeng pak e matur neng kulo yen metengi giyatni ndisek yo ya wes mbak,(W2.S1; 11-15) 
Ketika pertama kami mendengar bahwa suaminya ingin menikah lagi, informan nyaris tidak percaya dengan keputusan suaminya tersebut. Kemudian informan pergi kerumah orang tuanya dan saudara-saudaranya untuk meminta masukan terkait dengan keinginan suaminya tersebut. Akan tetapi orang tua informan dan saudara-saudaranya tidak percaya dengan apa yang informan sampaikan.

Oalah... pas niku aku anu mbak mlayu ngomahe wong tuaku..terus neng dulur dulur... ngomong yen bojoku ngono kae mbak... terus ya pas kui aku ngomong neng pak e tpi pak e dikandani sutris ro liyane ora nggugu.. (W2.S1; 29-32)

Pada awalnya informan menolak untuk dipoligami, informan dan keluarga mencoba menasihati suaminya agar mengurungkan niatnya tersebut. Namun karena suaminya sudah tidak bisa dinasihati dan agar tidak semakin memperkeruh suasana akhirnya informan dengan berat hati mengijinkan suaminya untuk menikah lagi.

\begin{abstract}
Nggeh niku, timbang rewang reweng, kulo jak gotong royong(W1.S1; 53). Nggeh pun kajenge, lawitne dikandanii mboten nggugu, pripon malah keewer tewer mbak mengke, nggih nggih...(W1.S1 ; 141-146) Soale kirangan pikiran kulo kok saget, pikiran kulo kok ikhlas, nek sek okeh-okeh yo mbak itung tugase $i$ yo kathah.(W1.S1; 287-289)Enggeh pon nyeserah, pon terserah. Dikandani mboten nggugu. (W1.S1; 86-87) Yo pokok e nek keno enggeh waune dikandani (ooh) nganu, dee koe wi timbange o yo wong mbokde anu. Yo wes rapopo wes ra kepikiran pie pie, ndadak rabi neh anak demene rekoso ngoten (enggeh) waune gek dereng. La terus dikandani mboten gugu, enggeh terserah. La wong kanton sek nglakoni nggeh mbak. (ooh enggeh) kanton kulo ngartos. (W1.S1; 91- 98)
\end{abstract}

\title{
Faktor-faktor yang membuat Informan bersedia untuk Dipoligami
}

Banyak hal yang menyebabkan informan bersedia untuk dipoligami, faktor-faktor tersebut diantaranya adalah: 1) Anak, Informan merasa kasian terhadap anak-anaknya kalau sampai akhirnya mereka bercerai maka kehidupan anak-anaknya akan hancur, 2) Calon Istri Suaminya sudah hamil, salah satu alasan lain yang membuat informan mengijinkan suaminya menikah lagi adalah karena calon istri kedua dari suaminya ternyata sudah hamil terlebih dahulu. Agar aib ini tidak menyebar kemana-mana, akhirnya informan mengijinkan suami nya untuk menikah lagi. 3) Suami informan mengancam akan menceraikannya jika tidak mengijinkannya menikah lagi. 
Tapi yo gandeng enek faktor misal ak pegatan mesakne anak anakku mbak.. (W2.SI: 106-107)

Mbok e ki aku nyenengi wong kipiye mbok...anu i aku ngetengi giyatni cah solo kono..ngonten mbak, terus yo aku pas kui mlayuomahewong tuaku karo rembukan ro dulur dulur... ngonten mbak. (W2.S1; 48-50)

Gandeng pon ke bacot timbange wiring,ngih mpon ....(W1.S1.:21)

Pas pak e nyampaine ajeng rabi niku ngih rodok horok mbk...la pie aku ya kaget pak e ngonten... Terus ps niku kulo ajeng pegatan kaleh pak e ning mikir anak kulo tidak do mawut kabeh mbk, pak e barang yora gelem megat aku... Horok e ki yo misal pak kae aku jarang omongan ngonten... tapi sui ning sui ngih biasa...(W2, S1: 48-52)

\section{Kehidupan Informan saat dipoligami}

Pada awal-awal kehidupan berpoligami, informan pernah merasa tidak nyaman dengan kehadiran istri kedua dalam kehidupan rumah tangganya. Akan tetapi seiring berjalannya waktu, informan bisa menerima kehadiran istri kedua suaminya tersebut dan bisa hidup dalam satu atap.

Sikapku pas niku anu mbak, pertama yo pie yo mbak ngono kae, dongkol e yo ono, hehehe ning ya yawes mbak sikapku mpun biasa mawon.. (W2.SI :86)

Setelah usaha informan untuk menasihati suami gagal, akhirnya informan mengikhlaskan suaminya untuk menikah lagi. Informan berharap keputusannya untuk mengikhlaskan suaminya menikah lagi dapat membuatnya tenang dan tidak membuatnya stress serta Informan mencoba mengambil hikmah dari kejadian tersebut. Namun ada beberapa syarat yang harus dipenuhi. Syarat tersebut diantaranya adalah: (1) istri kedua harus tetap menghargai istri pertama, (2) harus mau menyelesaikan permasalahan keluarga dengan cara bersama-sama dan tidak ada yang boleh iri dan dengki antara satu dengan yang lainnya.

Kulo mboten, mboten laer baten mbak. (hehehe) kajenge gotong royongg ngartos anak-anak pon do anu. mboten, laer baten.(W1.S1; 75-76)Pon ikhlas nek bojo kuli rabi niku pon ikhlas laer baten pon mboten enten roso nopo-nopo, anyel nopo niku pon mboten.(W1.S1; 81- 82)

Dasarku pkog e giyatni mboten ngungahi kulo damai gotong royong bareng bareng wis rapopo mbak....penting ora ono iri irinan ngonten, yen adil ngih pak e adil ngonten mawon (W2. SI : 79-82)

Ketika informan sudah resmi hidup berpoligami, informan senantiasa bermusyawarah dengan suami dan istri kedua dari suaminya untuk mengatasi permasalahan-permasalahan yang dihadapi dalam rumah tangga mereka. Mereka saling berkerjasama dan saling bantu membatu antara satu dengan yang lainnya. Setelah dipoligami, mereka hidup satu rumah dan bahkan satu kamar. 
Yen aku anu og mbak... paling rembukan bareng-bareng terus golek penak $e$, penting giyatni niku mboten ngungahi kulo(W2.S1; 41-42)

Dasarku pkog e giyatni mboten ngungahi kulo damai gotong royong bareng bareng wis rapopo mbak....penting ora ono iri irinan ngonten, yen adil ngih pak e adil ngonten mawon (W2. SI: 79-82)

Engeh mboten, mboten, enggeh mboten. Waune niku riwayate kiambak, tilem niku enggeh tunggal sak kamar...(W1.S1: 109-110)

Meskipun sudah hidup berpoligami, namun menurut informan tidak ada yang berubah dengan sikap suaminya. Suaminya masih bisa berbuat adil dalam memperlakukan keluarga mereka.

Mboten, mboten enten bedane....(W1.S1: 34).

\section{Respon keluarga dan tetangga terkait dengan kehidupan berpoligami}

Informan menjelaskan bahwa sebenarnya keluarga informan kurang setuju dengan keputusan suami informan untuk menikah lagi. Sehingga keluarga mencoba menasihati suami informan untuk mengurungkan niat nya tersebut. Namun karena usaha yang dilakukan oleh keluarga informan gagal, akhirnya keluarga informan menyerahkan segala keputusan kepada informan dan suaminya.

Enggeh pon nyeserah, pon terserah. Dikandani mboten nggugu. (W1.S1 ; $86-$ 87) Yo pokok e nek keno enggeh waune dikandani (ooh) nganu, dee koe wi timbange o yo wong mbokde anu. Yo wes rapopo wes ra kepikiran pie pie, ndadak rabi neh anak demene rekoso ngoten (enggeh) waune gek dereng. La terus dikandani mboten gugu, enggeh terserah. La wong kanton sek nglakoni nggeh mbak. (ooh enggeh) kanton kulo ngartos.(W1.S1 ; 91 - 98)

Masyarakat sekitar tempat tinggal informan tidak mempermasalahakan kehidupan keluarga informan setelah poligami. Masyarakat masih berperilaku biasa saja. Karena menurut informan, keluarga mereka sangat aktif dan selalu ikut berpartisipasi dalam setiap kegiatan yang ada di masyarakat.

Ngih mboten nopo-nopo oleh tonggo teparo ngih sae sedoyo, tonggone mboten nopo-nopo mboten enten sik iri, giyatni ki ya ramah tamah kaleh tanggane. Anu ngih rewang ngih nopo-nopo kon nopo ngih mangkat enten tiang loro yo tilikan, enek rewangan yo mangkat, yo pokog e biasa ngono lo mbak...(W1.S1 ; 149 155)

\section{Informan 2}

\section{Perasaan dan Sikap informan ketika Akan di Poligami}

Sebelum pernikahan informan tidak ada fikiran dan tidak pernah membayangkan bahwa akan dipoligami serta tidak ada kesepakatan poligami 
diawal pernikahannya. Setelah empat bulan menikah, suami informan mulai mengutarakan keinginan hatinya untuk berpoligami. Setelah informan mengetahui siapa yang ingin dinikahi oleh suaminya, informanpun langsung mengijinkan suaminya untuk berpoligami, karena ternyata yang ingin dijadikan istri kedua suaminya ternyata adalah sahabat informan sendiri. Karena informan sudah memahami karakter calon istri suaminya tersebut informan bersedia ketika diminta oleh suaminya untuk melamarkan wanita tersebut untuknya.

\begin{abstract}
iyaa, eh ndak mbak suami saya itu sudah ingin berpoligami itu sejak saya menikah sekitar berapa bulan yaa empat bulanan jadi sekitar empat bulanan itudulu pernah meminta izin untuk berpoligami dan aku pun mengizinkan manten anyar itu he he dan tak Tanya siapa itu orangnya ternyata sahabatku sendiri aku kenal dengan orangnya kenal baik dengan orangnya dan aku mengizinkan tapi ternyata setelah aku disuruh istilah aku nembung ke nglamarke gitu lho (W1.S2: 69-74)

opo eepertanyaan ini kan memang sebagian besar kan dari suami sedangkan sek tak alami itu aku yang mencarikan gitu. (W1.S2.11-13)

Jadi aku ndak ada pikiran kesitu suami tiba-tiba ingin mengutarakn seperti itu. (W1.S2.21-22)

eeewaktu itu mengajukan syarat seng penting aku kenal sama Orangnya itu (W1.S2: 44-45) yaa saya langsung eeapa ya langsung mengizinkan saya langsung mengizinkan dan pokok nya syaratnya Cuma satu itu aku kenal dengan orangnya ituu, (W1.S2: 52-52)
\end{abstract}

Kasus poligami yang terjadi pada informan memang berbeda dengan kasus-kasus polihami pada umumnya. Dimana pada umumnya suami yang meminta untuk berpoligami, namun dalam kasus informan ini, informanlah yang justru menawarkan kepada suami dan mencarikan calon untuk suaminya tersebut. Selain itu, agar kehidupan berpoligami yang akan mereka lakukan penuh dengan keberkahan, informan meminta kepada suami dan calon istri keduanya untuk sholat meminta petuntuk dari Allah.

tidak ada, dulu saya yang malah justruuu istilahnya nawari mbak nawari trusee dan apasuami sanggup ya monggo dan saya salah satu yang istilahe nglancarke lah sampe terjadi akad, akad pun aku yang ada ditengah-tenga he mbak (W1.S2: 113-117)

apa ssstt istilahnya udah dia udah serius udah serius tak suruh nyolatin semuanya aku juga sholat semuanya dan tiga-tiganya dah mantep baru (W1.S2: 173-175)

\title{
Faktor-faktor yang membuat Informan bersedia untuk Dipoligami
}

Poligami menurut informan bukanlah suatu masalah yang perlu dipermasalahkan. Poligami adalah syariat yang Allah syariatkan khususnya bagi 
yang mampu dan bisa berbuat adil. Bahkan ketika suami ingin berpoligami, informan langsung memberikan ijin poligami tersebut, namun ada satu syarat yang disyaratkan oleh informan, syarat tersebut adalah calon istri kedua dari suaminya harus wanita yang direkomendasikan oleh informan, artinya informanlah yang kan mencarikan istri kedua untuk suaminya.

Dalam kehidupan informan, poligami bukanlah hal yang baru. Informan sudah mengenal syariat poligami sejak masih muda. Ada beberapa hal yang membuat informan bersedia untuk dipoligami, diantaranya adalah: 1) Poligami adalah syariat Islam dan ada perintahnya dari Allah, 2) Sejak muda informan sudah memahami konsep tentang poligami, informan sudah belajar banyak tentag bab Poligami, 3) Orangtua informan juga pelaku poligami. Ketiga alasan inilah yang membuat informan mantap dan bersedia untuk dipologami.

“aku sudah paham dari dulu jadi sejak muda sejak muda itu aku sudah
memahami bab poligami dan aku tidak membenci masalah poligami dan aku
tidak menolak masalah poligami dan tidak istilahnya merintangi orang yang
berpoligami (W1.S2:26-29)
soalnya bapak ku kan juga berpoligami jadi coro poligami ki wes melekat di
hatiku gitu lho mbak(W1.S2:30-31)
alasannya ya karna memang itu istilahnya satu Udah perintah dari Allah
(W1.S2: 41-42)”

\section{Kehidupan Informan saat dipoligami}

Meskipun informan sudah sah menyandang status istri yang dipoligami, namun informan tidak pernah mengalami kecemasan yang berarti (kecemasan berat) terkait dengan kehidupan rumahtangganya. Hal ini disebabkan karena suami informan selalu terbuka kepadanya bahkan terkait dengan kehidupan suaminya dengan istri keduanya.

\footnotetext{
Selama ini ya mbak, selama ini karna suami saya yaa sangat terbuka sangat terbuka dengan saya apa pun kondisinya apapun yang terjadi dengan yang kedua saya tau semua gitu lho jadi ya Alhamdhulillah selama ini nggak ada kecemasan sing berat gitu lho mba, kecemasan sing berat nggak ada karna memang yang di tunjukan suami saya itu semakin kesini itu semakin menunjukan besar perhatiannya jadi aku nggak ada kecemasan sing berat gitu lho..(W1.S2: 125-133)
}

Informan menyampaikan bahwa setelah dipoligami, perilaku suami justru semakin baik, semakin sayang dan semakin romantis serta hubungan keluarga mereka semakin baik. Begitupula hubungan informan dengan istri kedua 
suaminya. Menurut informan, kedekatannya dengan istri kedua suaminya dikarenakan informanlah yang mencarikan calon istri untuk suaminya tersebut. Sehingga menurut informan, tidak ada masalah yang berarti dalam kehidupan rumah tangganya meskipun dipoligami.

\begin{abstract}
"Hubungan e yo semakin baik, kemaren udah tak jawab jadi semakin semakin apa yang saya rasakan setelah suami berpoligami itu suami tambah romantis, tambah baik, terus hubungan antaraa Eee..saya dan suami yo baik, suami dan anak-anakjuga baik" (W2.S2: 4-9)

Yo baik mbak soalnya kan yang istilahnya yang meee melancarkan yang melancarkan hubungan antara suami dan istri kedua kan saya jadi hubungannya baik seperti jadi saya menyayangi (suara kendaraan lewat) menyayangi istri calon istri kedua itu ya seperti saya menyayangi suami saya Eee apa sikap dari istri calon istri yang kedua itu juga baik jadi sama saya juga baik sama saya, sama anak-anak juga perhatian jadi ya baik-baik saja jadi gak ada masalah.(W2.S2: 17-26)
\end{abstract}

Meskipun informan tidak pernah merasakan kecemasan-kecemasan yang berat, namun sejujurnya informan mengakui bahwa masalah dalam rumah tangga pasti ada apalagi masalah dalam keluarga poligami. Namun menurut informan kecemasan tersebut bukan kecemasan terkait dengan kehidupan poligami seperti kecemasana kalau nantinya suami lebih memilih istri mudanya. Namun kecemasan yang dialami oleh informan adalah kecemasan akan kesehatan suaminya.

\begin{abstract}
kecemasan ringan ada mbak, ada ya mungkin kan orang berpoligami kanapa memang banyak masalah orang yang berumah tangga biasa aja banyak masalah tapi kan bagaimana pun setip oran gitu yo pasti banyak masalah orang yang lajang aja banyak masalah apalagi yang berumah tangga dan berpoligami tapi bagaimana cara kita mengatasi masalah itu gitu, kalau masalah kecil itu yang saya khawatirkan itu gini jadi mungkin itu kalau semakin suami banyak masalah banyak fikiran yang saya takutkan suami sakit sedangkan saya masih banyak anak banya ketanggungan seperti seperti itu lah jadi istilahnya kecemasan takut kehilangan takut ditinggal Eee.. Selamanya itu yang kecemasan kalau kecemasan yang berarti opo engko milih singgg enom ndak ada ndak ada sama sekali dan aku percaya itu bahwa aku percaya ke suami saya kalau suami saya itu ndak seperti itu gitu lho karna memang ditunjukan dari sikapnya sehari-hari perhatiannya sehari-hari (W1.S1 136-156)
\end{abstract}

Perselisihan antara informan dan istri kedua suminyapun akhirnya terjadi setelah 4 bulan kehidupan berpoligami berlangsung. Menurut informan, keretakan hubungan antara dirinya dengn istri kedua dari suaminya disebabkan karena masalah kecemburuan yang sering diperlihatkan oleh istri kedua. Akhirnya mereka memutuskan untuk pisah rumah. 
Pernah. Itu malah justru bukan awal mbak, bukan awal, itu malah pertengahan. (W1.S2:382-383)

Trus empat bulan dia istilahe njarak terus to, akhire daripada nanti malah ee..perang, tak suruh pindah, tak belikan rumah di sana, tak suruh pindah sana,

(W1.S2:512-514)

\section{Respon keluarga dan tetangga terkait dengan kehidupan berpoligami}

Meskipun informan tidak keberatan dengan keinginan suami untuk berpoligami. Namun keluarga dari informan, khususnya anak pertama informan dan Ibu Informan keberatan dengan niat sang menantu untuk berpoligami. Akan tetapi berbeda halnya dengan ayah informan yang justru memberikan kebebasan untuk untuk menantunya. Meskipun diawal proses berpoligami ibu informan menolak, namun pada akhirnya ibu informan mengijinkan menantunya untuk menikah lagi.

... hoo udah ngerti. Nangis. pokoknya ndak mau, bener bener ndak mau, saya jelasin akhirnya yowis sing penting mamah. Akhirnya seperti itu. (W1.S2:586588)

Keluarga sayaaa yang keberatan ibu, Ibu ya mungkin perasaan seorang perempuan kali ya mbak ya jadii kalau bapak sih terserah kowe sing ngelakoni kowe kalau ibu berulang kali istilahnya suruh berpikir lagi berpikir lagi itu ibu tapi ujung-ujungnya ya yo terserah kowe lah singngelakoni kowe, kowe iso ngelakoni, kowe iso kuat silahkan gitu Kalau dari keluarga suamii itu juga mengijinkan tidak ada kendala cuman ya ada nasehat lah ada nasehat buat yang kedua bukan buat saya tapi untuk yang kedua gitu ada beberapa sedikit nasehat atau yo istilahe jangan banyak menuntut karena memang disinibanyak banyak anak itu aja(W1.S2: 202-210)

Penolakan yang paling berat justru datangnya dari lingkungan dimana informan tinggal khususnya lingkungan tetangga dan masjid. Menurut informan, penolakan ini disebabkan karena masyarakat dimana informan tinggal masih awam terkait dengan perilaku berpoligami. Gunjingan hampir selalu didapatkan oleh informan, bahkan ada yang mengangkap bahwa informan stress dan gila karena mau menyetujui dan mencarikan calon istri untuk suaminya sendiri.

Justru yang paling berat itu dari lingkungan mbak (W1.S2: 223)

Jadi dari lingkungan karena memang lingkungan disini itu kan memang masalah seperti itu kan masih awam to mbak (W1.S2:227-228)

Jadi aku dibilang gila, dibilang Eee stress, dibilang ndak waras seperti itu dan mereka sampek nyamperi kesini sampek yahhss menghujat menghujat aku wesss sampek semua orang jadi Eee setiap aku lewat itu mereka EeeMenggunjingkan $a k u$, justru yang paling berat itu dari lingkungan, lingkungan rumah dan lingkungan masjid (W1.S2:231- 237) 
Cercaan, gunjingan dan ejekan-ejekan tersebut disikapi santai oleh informan. Informan cenderung santai dan tidak mau tau atas segala macam sikap warga tersebut.

Yo Alhamdulillah aku ini kan orangnya cuwek mbak mbuh ra ruh terserah kowe arep ngomongke aku koyok opo terserah itu hak mu seng penting aku enjoy sing penting aku seneng itu aja.. (W1.S2:242- 244)

\section{Informan 3}

\section{Perasaan dan Sikap Informan ketika Akan di Poligami}

Informan tidak pernah membayangkan kalau suatu saat akan dipoligami oleh suaminya terlebih lagi istri kedua dari suami nya adalah adik kandungnya sendiri. Hal ini terjadi karena adanya hubungan terlarang yang terjadi antara suami dan adik kandungnya. Selama ini adik kandung informan tinggal bersamanya dan disekolahkan oleh informan. Hubungan terlarang tersebut terjadi karena informan bekerja di sebuah parbrik yang ada di Kota Solo. Informan dalam setiap harinya selalu berangkat pagi dan pulang malam, sehingga informan tidak mengetahui apa yang terjadi dirumah dan yang dilakukan oleh suami dan adik kandungnya.

Enggak, enggak, wong itu adik saya sendiri o, saya kan nomor satu, itu nomor 3, kan ikut saya sekola, saya biayai sekolah sampai lulus SMP, saya kan kerja situ tak suruh momong anak saya yang nomor 1, 2. Saya kan berangkat pagi pulang sore, tapi nggak tahu itu kan dirumah sini...(W1.S3: 6-10)

Ketika mendengar bahwa suami informan sudah menghamili adik kandungnya, informan marah dan kecewa bahkan informan sempat ingin bunuh diri. Namun karena informan teringat dengan anak-anaknya yang masih kecil, akhirnya informan mengurungkan niatnya untuk bunuh diri. Informan merasa sakit hati terhadap suami dan adiknya, terlebih lagi selama ini informan sudah mengurus dan menyekolahkan adiknya tersebut.

Pertama ya, ya kaya gitu mbak, cuman dulu mau bunuh diri tapi anak saya masih kecil-kecil (W1. S3: 34-35)

Wa ya marah mbak, mau saya gebuk mau saya apa, ning yo bagaimana udah jadi satu sama saya (W1. S3 : 76-77)

Wah dulu luka sekali mbak sakiiit sekali (W2. S3 : 302)

\section{Faktor-faktor yang membuat Informan bersedia untuk Dipoligami}

Sampai detik ini informan masih belum bisa menerima dan memberikan 
ijin untuk suaminya menikahi adiknya. Informan secara hukum masih menyandang status istri yang sah karena tidak ada perceraian diatara mereka. meskipun suami dan adiknya sudah tinggal bersama dan diakruniai dua anak, namun secara hukum pernikahan mereka tidak sah karena tidak tercatat dalam catatan sipil.

Saya nggak mengijinkan (W1. S3 : 54)

Ya minta ijin, terus saya nggak mau, sebelumnya kan sudah bilang sama anakanak saya ya tidak usah, "rasahbu westekne wae" (W2. S3: 83-86)

Heeh pelan-pelan udah tak ikhlaske sekarang. Tapi kalok suruh minta tanda tangan ya tetap gak maau saya(W2. S3 : 321-324)

\section{Kehidupan Informan saat dipoligami}

Informan menjelaskan bahwa informan sering mengalami kekerasan secara fisik yang dilakukan oleh suaminya sendiri. Hal ini terjadi karena adik informan yang juga istri kedua dari suami informan sering mengadu kepada suaminya terkait dengan perlakuan informan kepadanya. Karena adanya laporan tersebut, tidak jarang suaminya melakukan kekerasan secara fisik kepada informan. Hal ini sangat berbeda dengan kehidupan informan sebelum dipoligami oleh suaminya. Menurut informan perilaku kasar yang ditunjukkan oleh suaminya bermula sejak suaminya meminta ijin untuk menikahi adiknya namun tidak diberikan ijin oleh informan.

\footnotetext{
Dulu saya sering diajar lho mbak, uhmmm sering diajar sama laki saya. (W2, S3: 128-130)

Itu bilang anu pokoknya biar laki saya marah. Laki saya marah saya sering diajar.(W2, S3: 136-138)

saya sampe ndelik disini lho mbak, suami saya nyari (W2,S3: 140-141) saya dulu sering dikoploki sampe 3 hari nggak keluar saya (W2, S3:164-165)

Dulu ndak kasar (W2, S3: 155) Uuи kasar itu mbak, dulu endak lho. (W2. S3 : 150)Dulu ndak kasar, saya trus, saya suruh tanda tangan nggak mau(W2. S3 : 155 - 156)
}

Meskipun informan tiggal satu atap dengan suami dan istri keduanya namun selama lebih kurang $40^{\text {th }}$ sejak terjadinya poligami tersebut, informan tidak pernah bertegur sapa dengan istri kedua dari suami yang juga adalah adik kandungnya sendiri.

Gk pernah bicara belas (W1,S3 289), Udah 40-an tahun ndak bicara (W1, S3 296297)

Heeh, tapi saya ndak pernah bicara, diam..jadi kalau situ masuk saya keluar, ya kalau duduk gitu yasudah biasa gini, tapi ndak pernah mbak.. saya ndak mau mbak 
bicara(W1. S3 : 27 - 30) diam diam semua pokonya jaga diri sendiri (W1. S3 : 57 -58)

\section{Respon keluarga dan tetangga terkait dengan kehidupan berpoligami}

Keluarga besar informan sangat marah atas kejadian tersebut, khususnya orang tua informan. Bahkan ayah informan sampai meninggal karena adanya permasalahan ini. Respon masyarakat sekitar seolah diam saja namun menurut informan apa yang terjadi tentang keluarganya dibelakang tetap menjadi bahan omongan.

\footnotetext{
Tahu yang marah mbak, suruh..ibu saya sama bapak saya suruh pulang kesana (W1. S3:98)

Sampai bapak saya meninggal tho mbak..ya gara-gara itu.. (W1. S3: 105)

Yaa, diem saja mbak (W1. S3: 122), Pembicaraan? ohh ya tetap itu, pasti (W1. S3: 125)
}

\section{Pembahasan}

Beberepa penelitian terdahulu diantaranya oleh Sunaryo (2010) yang berjudul "Poligami Di Indonesia (Sebuah Analisis Normatif-sosiologis)" dengan simpulan penelitian bahwa kontroversi seputar poligami di Indonesiatidak bisa dipisahkan dari beragam faktor, antara lain: Pertama, problem penafsiran teks-teks keagamaan. Kedua adanya perspektif yang berbeda mengenai peran dan fungsi gender di masyarakat. Ketiga, aturan hukum yang tidak diimbangi dengan kesadaran serta kepatuhan hukum di masyarakat. Perbedaan dalam konteks penelitian ini, penulis menjawab pertanyaan penelitian yaitu bagaimana gambaran kehidupanpada wanita yang di poligami dalam prespektif psikologi sosial.

Berdasarkanhasil wawancara dari ketiga informan, terdapat beberapa temuan manarik. Berdasarkan prespektif psikologi sosial, penulis menganalisis berdasarkan aspek dan faktor penerimaan diri menjadi empat kategorisasi yaitu: (1) Perasaan dan Sikap informan ketika Akan di Poligami, (2) Faktor-faktor yang membuat Informan bersedia untuk Dipoligami, (3) Kehidupan Informan saat dipoligami, (4)Respon keluarga dan tetangga terkait dengan kehidupan berpoligami. Secara sederhana rekapitulasi wawancara ketiga informan dapat dilihat pada tabel 1 sebagai berikut: 
Tabel 1

Rekapitulasi Wawancara Ketiga Informan

\begin{tabular}{|c|c|c|c|c|}
\hline No & Kategori & Informan 1(M.P) & Informan 2(M) & Informan 3(I) \\
\hline 1 & $\begin{array}{l}\text { Perasaan dan } \\
\text { Sikap } \\
\text { informan } \\
\text { ketika Akan } \\
\text { di Poligami }\end{array}$ & $\begin{array}{l}\text { Tidak percaya dan } \\
\text { sedih. }\end{array}$ & $\begin{array}{l}\text { - } \text { Tidak cemas } \\
\text { - menawarkan kepada suami } \\
\text { dan mencarikan calon istri }\end{array}$ & $\begin{array}{l}\text { - Marah, kecewa, sakit hati, } \\
\text { bahkan informan sempat } \\
\text { ingin bunuh diri. }\end{array}$ \\
\hline 2 & $\begin{array}{l}\text { Faktor- } \\
\text { faktor yang } \\
\text { membuat } \\
\text { Informan } \\
\text { bersedia } \\
\text { untuk } \\
\text { Dipoligami }\end{array}$ & $\begin{array}{l}\text { - Anak (jika bercerai } \\
\text { maka kehidupan } \\
\text { anak-anaknya akan } \\
\text { hancur). } \\
\text { - Calon istri sudah } \\
\text { hamil diluar nikah. } \\
\text { Diancam akan } \\
\text { dicerai jika tidak } \\
\text { diijinkan poligami. } \\
\text { Suaminya sudah tidak } \\
\text { bisa dinasihati dan } \\
\text { agar supaya tidak } \\
\text { semakin } \\
\text { memperkeruh } \\
\text { suasana akhirnya istri } \\
\text { memberikan ijin } \\
\text { untuk berpoligami. } \\
\text { Suami dan istri kedua } \\
\text { menyetujui syarat } \\
\text { yang diajukan } \\
\text { informan: Beberapa } \\
\text { syarat yang harus } \\
\text { dipenuhi, yaitu: (1) } \\
\text { istri kedua harus } \\
\text { menghargai istri } \\
\text { pertama, } \\
\text { menyelesaikan } \\
\text { permasalahan } \\
\text { keluarga dengan cara } \\
\text { bersama-sama dan } \\
\text { tidak ada yang boleh } \\
\text { iri dan dengki. }\end{array}$ & $\begin{array}{l}\text { - Poligami adalah syariat } \\
\text { Islam dan ada perintahnya } \\
\text { dari Allah. } \\
\text { - Sudah memahami konsep } \\
\text { poligami } \\
\text { - Orangtua informan juga } \\
\text { pelaku poligami. }\end{array}$ & $\begin{array}{l}\text { - Informan tidak memberikan } \\
\text { ijin poligami. } \\
\text { - Status istri kedua suaminya } \\
\text { tidak sah secara hukum. } \\
\text { Informan tidak mau } \\
\text { diceraikan dan tidak mau } \\
\text { dipologami. }\end{array}$ \\
\hline 3 & $\begin{array}{l}\text { Kehidupan } \\
\text { Informan } \\
\text { saat } \\
\text { dipoligami }\end{array}$ & $\begin{array}{l}\text { - Hidup satu rumah, } \\
\text { bahkan satu kamar. } \\
\text { - Suaminya masih bisa } \\
\text { berbuat adil. }\end{array}$ & $\begin{array}{l}\text { Suami informan selalu } \\
\text { terbuka kepadanya bahkan } \\
\text { terkait dengan kehidupan } \\
\text { suaminya dengan istri } \\
\text { keduanya. } \\
\text { - Setelah dipoligami, perilaku } \\
\text { suami justru semakin baik, } \\
\text { semakin sayang dan semakin } \\
\text { romantis serta hubungan } \\
\text { keluarga mereka semakin } \\
\text { baik. Begitupula hubungan } \\
\text { informan dengan istri kedua } \\
\text { Empat bulan kehidupan } \\
\text { poligami berlangsung, }\end{array}$ & $\begin{array}{l}\text { - Sering mengalami kekerasan } \\
\text { secara fisik yang dilakukan } \\
\text { oleh suaminya sendiri. } \\
\text { - Sangat berbeda dengan } \\
\text { kehidupan informan sebelum } \\
\text { dipoligami. } \\
\text { - Informan tidak pernah } \\
\text { bertegur sapa dengan istri } \\
\text { kedua dari suami yang juga } \\
\text { adalah adik kandungnya } \\
\text { sendiri. }\end{array}$ \\
\hline
\end{tabular}




\begin{tabular}{|c|c|c|c|c|}
\hline No & Kategori & Informan 1(M.P) & Informan 2(M) & Informan 3(I) \\
\hline 4 & $\begin{array}{l}\text { Respon } \\
\text { keluarga dan } \\
\text { tetangga } \\
\text { terkait } \\
\text { dengan } \\
\text { kehidupan } \\
\text { berpoligami }\end{array}$ & 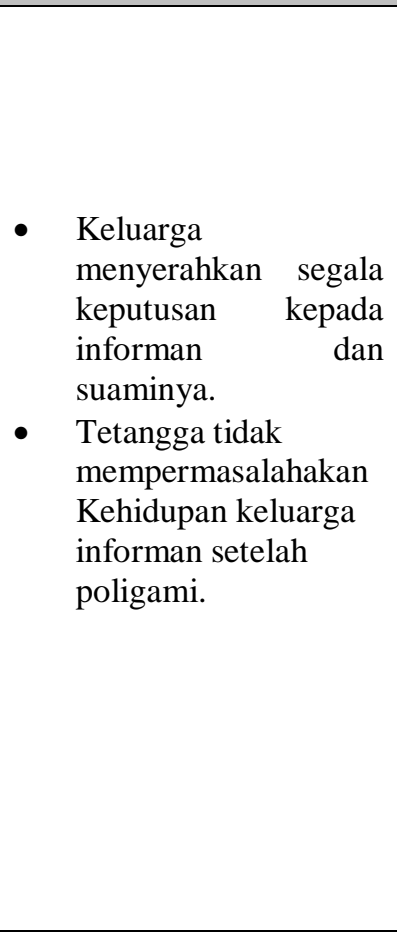 & $\begin{array}{l}\text { kecemburuan yang sering } \\
\text { diperlihatkan oleh istri } \\
\text { kedua. Akhirnya mereka } \\
\text { memutuskan untuk pisah } \\
\text { rumah. } \\
\text { Keluarga dari informan, } \\
\text { khususnya anak pertama } \\
\text { informan dan Ibu Informan } \\
\text { keberatan dengan niat sang } \\
\text { menantu untuk berpoligami. } \\
\text { Akan tetapi berbeda halnya } \\
\text { dengan ayah informan yang } \\
\text { justru memberikan } \\
\text { kebebasan untuk untuk } \\
\text { menantunya. } \\
\text { Ada penolakan dan } \\
\text { gunjingan dari lingkungan } \\
\text { tetangga dan masjid, } \\
\text { mengangkap bahwa } \\
\text { informan stress dan gila } \\
\text { karena mau menyetujui dan } \\
\text { mencarikan calon istri untuk } \\
\text { suaminya sendiri. }\end{array}$ & $\begin{array}{l}\text { - Keluarga besar informan } \\
\text { sangat marah, khususnya } \\
\text { orang tua informan. Bahkan } \\
\text { ayah informan sampai } \\
\text { meninggal karena adanya } \\
\text { permasalahan ini. } \\
\text { Masyarakat sekitar seolah } \\
\text { diam saja, namun tetap } \\
\text { menjadi bahan omongan. }\end{array}$ \\
\hline
\end{tabular}

Berdasarkan uraian-uraian diatas, maka dapat disimpulkan bahwa terdapat temuan-temuan menarik dan unik dari ketiga informan, pada kategoriperasaan dan sikap informan ketika akan di poligami, pada informan MP dan I muncul perasaan tidak percaya, sedih, marah, kecewa, dan sakit hati. Namun pada informan $M$ tidak muncul kecemasan pada dirinya. terkait sikap ketika dipoligami, ketiga informan juga menyatakan perbedaan. Informan MP menyatakan suami sudah tidak bisa dinasehati dan agar supaya tidak semakin memperkeruh suasana, informan M Justru bersikap menawarkan kepada suami dan mencarikan calon istri, lain halnya dengan I yang sempat ingin bunuh diri, karena mengingat anaknya masih kecil-kecil, akhirnya informan mengurungkan niatnya untuk bunuh diri.

Pada katergorifaktor-faktor yang membuat informan bersedia untuk dipoligami, informan MP menjelaskan ada tiga alasan mendasar kenapa dia bersedia dipoligami yaitu: 1) anak, jika bercerai maka kehidupan anak-anaknya akan hancur, 2) calon istri sudah hamil diluar nikah, 3) diancam akan dicerai jika tidak diijinkan poligami. Seperti halnya informan MP, informan M juga 
mempunyai tiga alasan, alasan pertama karena Poligami adalah syariat Islam dan ada perintahnya dari Allah. Kedua, informan sudah memahami konsep poligami. Ketiga, Orangtua informan juga pelaku poligami. Sedangkan informan I masih belum bisa menerima dan memberikan ijin untuk suaminya menikahi adiknya karena masih merasakan marah, kecewa, dan sakit hati kepada suami dan adiknya yang menjalin hubungan terlarang.

Dalam kategori kehidupan informan saat dipoligami, informan MP pada awalnya tidak nyaman dengan kehadiran istri kedua, karena informanya memberi dua syarat yaitu istri kedua harus menghargai istri pertama dan menyelesaikan segala masalah keluarga harus bersama-sama, mereka hidup satu rumah bahkan satu kamar. Informan M menyatakan suami selalu terbuka dengan kehidupan istri kedua, suami semakin baik, sayang, dan romantis. Namun karena ada kecemburuan dari istri kedua, akhirnya mereka pisah rumah. Berbeda dengan MP dan M, informan I justru sering mengalami kekerasan secara fisik oleh suaminya, sangat berbeda dengan kehidupan informan sebelum dipoligami, lebih parahnya lagi informan tidak pernah bertegur sapa dengan istri kedua dari suami yang juga adalah adik kandungnya sendiri.

Sedangkan kategori respon keluarga dan tetangga terkait dengan kehidupan berpoligami, respon keluarga informan MP menyerahkan segala keputusan kepada informan dan suaminya, sedangkan tetangga tidak mempermasalahakan kehidupan keluarga informan setelah poligami. Pada informan M keluarga dari informan, khususnya anak pertama informan dan Ibu Informan keberatan dengan niat sang menantu untuk berpoligami. Akan tetapi berbeda halnya dengan ayah informan yang justru memberikan kebebasan untuk untuk menantunya. Ada penolakan dan gunjingan dari lingkungan tetangga dan masjid, mengangkap bahwa informan stress dan gila karena mau menyetujui dan mencarikan calon istri untuk suaminya sendiri. Sangat jauh berbeda dengan MP dan $\mathrm{M}$, respon kelurga besar informan I sangat marah, khususnya orang tua informan. Bahkan ayah informan sampai meninggal karena adanya permasalahan ini. Sedangkan respon masyarakat sekitar seolah diam saja, namun tetap menjadi bahan omongan. 


\section{Kesimpulan \& Saran}

\section{Kesimpulan}

Pada kategori perasaan dan sikap informan ketika akan di poligami, muncul perasaan tidak percaya, sedih, marah, kecewa, dan sakit hati. Terdapat pebedaan sikap dari ketiga informan ketikaakan dipoligami, yaitu suami sudah tidak bisa dinasehati dan agar supaya tidak semakin memperkeruh suasana, menawarkan kepada suami dan mencarikan calon istri, dan sempat ingin bunuh diri

Katergori faktor-faktor yang membuat informan bersedia untuk dipoligami, yaitu anak, calon istri sudah hamil di luar nikah, mendapat ancaman untuk dicerai, syariat Islam dan ada perintahnya dari Allah, sudah memahami konsep poligami, dan Orangtua informan juga pelaku poligami.

Kategori kehidupan informan saat dipoligami, mereka hidup satu rumah bahkan satu kamar, suami selalu terbuka dengan kehidupan istri kedua, suami semakin baik, sayang, dan romantis. Namun karena ada kecemburuan dari istri kedua, akhirnya mereka pisah rumah. Berbeda dengann dua informan sebelumnya, informan ketiga sering mengalami kekerasan secara fisik oleh suaminya, sangat berbeda dengan kehidupan informan sebelum dipoligami, lebih parahnya lagi informan tidak pernah bertegur sapa dengan istri kedua dari suami yang juga adalah adik kandungnya sendiri.

Kategori respon keluarga dan tetangga terkait dengan kehidupan berpoligami, ada temuan yang beragam kaitanya respon keluarga, ada keluarga yang menyerahkan segala keputusan kepada informan dan suaminya, keluarga dari informan, khususnya anak pertama informan dan Ibu Informan keberatan dengan niat sang menantu untuk berpoligami. Ada pula keluarga yang marah besar karena terjadi hubungan terlarang antara suami dan adik kandung informan. Sedangkan respon tetangga atau lingkungan antara lain tidak mempermasalahakan kehidupan keluarga informan setelah poligami, ada penolakan dan gunjingan dari lingkungan tetangga dan masjid, mengangkap bahwa informan stress dan gila karena mau menyetujui dan mencarikan calon istri untuk suaminya sendiri. Masyarakat sekitar seolah diam saja, namun tetap menjadi bahan pembicaraan. 


\section{Saran}

Bagi peneliti selanjutnya, diharapkan dapat mengembangkan penelitian ini dengan menentukan informan wanita yang dipoligami yang lebih banyak dan diambil dari beberapa Kota lain selain Kota Surakarta. Metode, bisa memakai penggabungan metode seperti observasi serta disiplin ilmu sosial lainya seperti sosiologi, antropologi, theology, dan psikologi indigenous. Bagi masyarakat, diharapkan dapat menjadikan hasil penelitian ini sebagai salah satu informasi untuk lebih bisa memahami manusia dalam konteks kehidupan berpoligami. Bagi pemerintah, hasil penelitian ini dapat memberikan sumbangsih bagi pembuat kebijakan (undang-undang) tentang poligami.

\section{DAFTAR PUSTAKA}

Husein, A. 2007. Hitam Putih Poligami . Jakarta: Lembaga Penerbit FE UI.

Ma'ruf, Amar . 2013. Implementasi Peraturan Perkawinan dan Perceraian PNS dan Pejabat. Tesis. UIN Sunan Kalijaga Yogyakarta.

Machali, R. 2005. Wacana Poligami di Indonesia. Bandung: Mizan

Marzuki, 2005. Poligami Dalam Hukum Islam. Jurnal CIVICS, Media Kajian Kewarganegaraan, Jurusan Pendidikan Kewarganegaraan dan Hukum Fakultas Ilmu Sosial dan Ekonomi, Universitas Negeri Yogyakarta Vol. 2 No. 2, Desember 2005 pp.1-10

Mulia,S.M. 2004. Islam. Jakarta: Gramedia Pustaka Utama

Nurmila, Nina. 2015. Pengaruh Budaya Patriarki Terhadap Pemahaman Agama Dan Pembentukan Budaya. Jurnal KARSA, Vol. 23 No. 1, Juni 2015

Sugiyono. 2010. Metodologi Penelitian Pendidikan; Pendekatan Kualitatif, Kualitatif, $R \& D$. Bandung; Alfabeta

Sunaryo, A. 2010. Poligami Di Indonesia (Sebuah Analisis Normatif-Sosiologis). Jurnal Yinyang, Pusat Studi Gender STAIN Purwokerto Vol.5 No.1 JanJun 2010 pp.143-167

https://tirto.id/mengapa-poligami-jadi-masalah-dcbp diakses pada Sabtu, 20 April 2019. 